\title{
Acute cytokine-mediated downregulation of the zinc transporter ZnT8 alters pancreatic $\beta$-cell function
}

\author{
Malek El Muayed*, Liana K Billings ${ }^{1, *}$, Meera R Raja ${ }^{2, *}$, Xiaomin Zhang ${ }^{3}$, Paul J Park ${ }^{4}$, Marsha V Newman, \\ Dixon B Kaufman ${ }^{3}$, Thomas V O'Halloran² and William L Lowe Jr \\ Division of Endocrinology, Metabolism and Molecular Medicine, Feinberg School of Medicine, Northwestern University, 303 East Chicago Avenue, \\ Tarry 15-755, Chicago, Illinois 60611, USA \\ ${ }^{1}$ Massachusetts General Hospital, Harvard University, 55 Fruit Street, Boston, Massachusetts 02114, USA \\ ${ }^{2}$ The Chemistry of Life Processes Institute and Department of Chemistry, Northwestern University, 2145 Sheridan Road, Evanston, Illinois 60208-3113, USA \\ ${ }^{3}$ Division of Transplant Surgery, Feinberg School of Medicine, Northwestern University, 303 East Chicago Avenue, Chicago, Illinois 60611, USA \\ ${ }^{4}$ Northwestern University, 2145 Sheridan Road, Evanston, Illinois 60208, USA \\ (Correspondence should be addressed to M El Muayed; Email: m-muayed@northwestern.edu)
}

*(M El Muayed, L K Billings and M R Raja contributed equally to this work)

\begin{abstract}
Genetic studies suggest that $\mathrm{Zn}$ transporters such as ZnT8 play a role in insulin secretion by pancreatic $\beta$-cells; however, little is known about the dynamic roles of $\mathrm{Zn}$ trafficking pathways on $\beta$-cell physiology. To test the acute effects of the inflammatory cytokines interleukin $1 \beta$ (IL1 $\beta$ ) and tumor necrosis factor $\alpha(\mathrm{TNF} \alpha)$ on $\mathrm{Zn}$ homeostasis, the mRNA expression profile of $\mathrm{Zn}$ transporters of the $\mathrm{ZnT}$ and ZIP families was examined. Exposure of MIN6 cells or primary murine islets to IL1 $\beta$ or TNF $\alpha$ altered the mRNA expression profile of $\mathrm{Zn}$ transporters; most notable was decreased $\mathrm{ZnT}$ 8 mRNA levels. siRNA-mediated gene knockdown was used to examine the effects of decreased $\mathrm{ZnT} 8$ expression in primary
\end{abstract}

dispersed murine islet cells from C57/BL6 mice and MIN6 cells. ZnT8 knockdown in these murine islets led to reduced glucose stimulated insulin secretion without altering the total cellular insulin content or cell viability at normal or supraphysiological $\mathrm{Zn}$ concentrations. The labile $\mathrm{Zn}$ content determined by flow cytometry after loading with the Zn-specific sensor FluoZin-3 AM was decreased in MIN6 cells following ZnT8 knockdown or IL1 $\beta$ treatment. These results suggest that an acute decrease in ZnT8 levels impairs $\beta$-cell function and $\mathrm{Zn}$ homeostasis, and may contribute to inflammatory cytokine-induced alterations in $\beta$-cell function. Journal of Endocrinology (2010) 206, 159-169

\section{Introduction}

A low level chronic inflammatory state with elevated circulating inflammatory cytokine levels is thought to be an important contributor to the development of type 2 diabetes mellitus (T2DM). Impaired function of insulin secreting $\beta$-cells after exposure to the inflammatory cytokines interleukin $1 \beta$ (IL1 $\beta$ ) or tumor necrosis factor $\alpha$ (TNF $\alpha$ ) has been shown in human and rodent $\beta$-cells as well as in MIN6 cells, a $\beta$-cell line. Several mechanisms for this effect have been implicated (Xenos et al. 1992, 1993, 1994, Corbett \& McDaniel 1995, Rabinovitch \& Suarez-Pinzon 1998, Wu et al. 2001, Donath et al. 2008). Altered expression of several genes involved in $\beta$-cell function is thought to be one of the mechanisms underlying this effect of cytokines (Donath et al. 2008).

$\mathrm{Zn}$ is the second most abundant transition metal in mammals (Wallwork et al. 1983, Milne et al. 1985, Ward \& Mason 1987) and is utilized in a number of biological processes (Cousins et al. 2006). Zn homeostasis is tightly regulated on the cellular and systemic level through various mechanisms (Outten \& O'Halloran 2001, Cousins et al. 2006) and is of particular importance to pancreatic $\beta$-cell physiology (Chausmer 1998, Dodson \& Steiner 1998, Chimienti et al. 2005, 2006, Lemaire et al. 2009). $\beta$-Cells have exceedingly high intracellular concentrations of $\mathrm{Zn}$, particularly within secretory vesicles, where $\mathrm{Zn}$ facilitates the packaging of insulin into hexamers (Figlewicz et al. 1984, Dodson \& Steiner 1998, Chimienti et al. 2006, Lemaire et al. 2009). In order to utilize $\mathrm{Zn}$, the $\beta$-cells require the trafficking of $\mathrm{Zn}$ across cell and vesicular membranes, mainly through members of the $\mathrm{Zn}$ transporter ( $\mathrm{ZnT}, S L C 30 A$ ) and Zrt-Irt-like protein (ZIP, SLC39A) transporter families. These facilitate $\mathrm{Zn}$ diffusion out of or into the cytoplasm respectively. The $\mathrm{Zn}$ transporter encoded by SLC30A8, ZnT8, plays a particularly important role in $\mathrm{Zn}$ homeostasis in $\beta$-cells (Chimienti et al. 2005, 2006, Lemaire et al. 2009). ZnT8 is highly expressed in $\beta$-cells (Chimienti et al. 2005, Mocchegiani et al. 2008), and 
localizes mainly to the membranes of secretory vesicles in $\beta$-cells (Chimienti et al. 2006). Other genetic variations in SLC30A8 have been found to be associated with fasting glucose levels (Dupuis et al. 2010). Strong association in humans has been demonstrated between a nonsynonymous single-nucleotide polymorphism rs1326634 in SLC30A8, and increased risk for the development of T2DM or $\beta$-cell dysfunction (Saxena et al. 2007, Scott et al. 2007, Sladek et al. 2007, Zeggini et al. 2007, Boesgaard et al. 2008, Hertel et al. 2008, van Hoek et al. 2008, Horikawa et al. 2008, Omori et al. 2008, Wu et al. 2008, Xiang et al. 2008). Other genetic variations in SLC30A8 have been found to be associated with fasting glucose levels (Dupuis et al. 2010). Recently, three studies described impaired $\mathrm{Zn}$ accumulation in secretory vesicles of islets isolated from $\mathrm{ZnT} 8$ knockout mice. Impaired $\beta$-cell function was present under certain age and high-fat dietary conditions (Lemaire et al. 2009, Nicolson et al. 2009, Pound et al. 2009). This highlighted the deleterious effects of a chronic and complete loss of ZnT8 function on islet cell physiology, and the likely role of compensatory and environmental factors in this process.

Given the importance of well-calibrated $\mathrm{Zn}$ homeostasis for $\beta$-cell physiology, we examined whether the effects of the cytokines IL1 $\beta$ and TNF $\alpha$ on $\beta$-cell function may be mediated, in part, through altered expression of $\mathrm{Zn}$ transporters. We examined the effect of treating MIN6 cells with these cytokines on the expression of $\mathrm{Zn}$ transporters in the ZIP and ZnT families. Additionally, we examined the consequences of the most significant cytokine-induced alteration in $\mathrm{Zn}$ transporter expression, decreased expression of $\mathrm{ZnT}$ 8, in MIN6 cells and primary murine islets.

\section{Materials and Methods}

\section{Islet purification}

Islets from 10 to 14 weeks old C57BL/6 male mice (Jackson Laboratories, Bar Harbor, ME, USA) were isolated as described previously (Blomeier et al. 2006). After washing, the islets were handpicked and counted under microscopic guidance. All studies were approved by the Northwestern University Animal Care and Use Committee.

\section{MIN6 cell culture}

MIN6 cells were a gift from Dr Junichi Miyazaki (Osaka University Medical School, Osaka, Japan), and were grown and maintained as described previously (Miyazaki et al. 1990). Cells between passages 28 and 35 were used.

\section{Cytokine treatment}

Cytokine treatment was performed as previously reported with modifications (Chin-Chance et al. 2006). Briefly, MIN6 cells between passages 28 and 34 were plated at a density of $2 \times 10^{6}$ cells per $60-\mathrm{mm}$ dish. Forty-eight hours after plating, the culture medium was exchanged for serum reduced culture medium containing $1 \%$ heat inactivated fetal bovine serum (FBS) supplemented with either no cytokines, $5 \mathrm{ng} / \mathrm{ml}$ murine IL1 $\beta, 10 \mathrm{ng} / \mathrm{ml}$ murine TNF $\alpha$, or a combination of both (R\&D Systems, Minneapolis, MN, USA). The cells were treated with cytokines for 6,24 , or $48 \mathrm{~h}$. For studies with murine islets, purified islets were incubated for $24 \mathrm{~h}$ in RPMI 1640 (ATCC, Manassas, VA, USA) supplemented with $1 \%$ non-heat inactivated FBS. The media were supplemented with either no cytokines, $5 \mathrm{ng} / \mathrm{ml}$ IL1 $\beta$, or $10 \mathrm{ng} / \mathrm{ml} \mathrm{TNF} \alpha$.

\section{$m R N A$ extraction and real-time PCR}

RNA was extracted from MIN6 and dispersed murine islet cells using Trizol reagent (Invitrogen) according to the manufacturer's instructions. RNA was extracted from intact murine islets using the RNAeasy Mini kit (Qiagen) according to the manufacturer's recommendations. The iScript cDNA synthesis kit (Bio-Rad) was used for reverse transcription of $0.5 \mu \mathrm{g}$ RNA following treatment with DNAse (Turbo DNAse kit, Ambion, Austin, TX, USA) according to the manufacturer's instructions. Real-time PCR was performed using the SYBR-Green super mix reagent (Bio-Rad) and the Bio-Rad iCycler PCR system. Primers for ZIP1 through 14, ZnT1 through 10, and $\beta$-actin, and $18 \mathrm{~S}$ (idtDNA, Coralville, IA, USA) were used in the PCRs. The sequences for the real-time PCR primers are listed in Supplementary Table 1, see section on supplementary data given at the end of this article. For real-time PCR, an initial denaturation step at $95^{\circ} \mathrm{C} \times 5 \mathrm{~min}$ was followed by 40 cycles at $95^{\circ} \mathrm{C} \times 15 \mathrm{~s}$ and $60^{\circ} \mathrm{C} \times 30 \mathrm{~s}$. A melt curve analysis was performed by incubating the reaction at $95{ }^{\circ} \mathrm{C} \times 1 \mathrm{~min}$, cooling to $60^{\circ} \mathrm{C}$ for $1 \mathrm{~min}$, and then increasing the temperature $0.5^{\circ} \mathrm{C}$ every $10 \mathrm{~s}$ up to $100^{\circ} \mathrm{C}$. All primers were validated using mRNA from mouse islets, MIN6 cells, and embryoid bodies prepared from murine embryonic stem cells. $2 \%$ agarose gel electrophoresis demonstrated a product of the expected size for all the ZnTs and ZIPs. Melt curve analyses demonstrated a single PCR product for each reaction. The $\Delta-\Delta C_{\mathrm{t}}$ method was used to calculate the relative level of mRNA of the gene of interest compared with the control condition after normalizing using the level of $\beta$-actin mRNA (Livak \& Schmittgen 2001). $18 \mathrm{~S}$ was used as an additional normalizer for experiments comparing MIN6 and primary islet $\mathrm{Zn}$ transporter expression profiles.

\section{MIN6 cell imaging}

Untreated live MIN6 cells were imaged following incubation for $1 \mathrm{~h}$ in phenol red-free DMEM media (Invitrogen) supplemented with the labile Zn-specific fluorescent sensor Fluozin-3-AM (Invitrogen) at a concentration of $5 \mu \mathrm{M}$. The images were obtained on an IX2-DSU/BX-DSU spinning disc confocal microscope (Olympus, Center Valley, PA, USA) 
in the Northwestern University cell imaging facility. Images were analyzed with Metamorph software (Universal Imaging Corp., Downington, PA, USA).

\section{Flow cytometry}

Flow cytometry was carried out $72 \mathrm{~h}$ after transfection with siRNA or after treatment with IL1 $\beta$ for $24 \mathrm{~h}$. Cells were washed twice with MIN6 cell culture medium containing 1 or $15 \%$ heat-inactivated FBS for IL1 $\beta$ or ZnT8 knockdown experiments respectively. Cells were subsequently incubated for $1 \mathrm{~h}$ in basic media supplemented with $2 \mathrm{mM}$ FluoZin-3 AM (Invitrogen) and $1 \mathrm{mM}$ CellTrace Red (Invitrogen) at $37^{\circ} \mathrm{C}$ in $5 \% \mathrm{CO}_{2}$. Cells were then washed twice with cell culture medium and once with PBS. The cells were dispersed using $0 \cdot 05 \%$ trypsin, collected by centrifugation, resuspended in PBS, and passed through a $70-\mathrm{mM}$ Cell Strainer (BD Biosciences, Bedford, MA, USA). Cells were analyzed on an LSR II system (BD, Franklin Lakes, NH, USA). Only the $\mathrm{Zn}$ fluorescence of live, single cells, as determined by the CellTrace side scatter and forward scatter fluorescence patterns, was analyzed.

\section{ZnT8 knockdown in dispersed islet cells or MIN6 cells}

Islets harvested from C57BL/6 mice were washed with PBS (Invitrogen), pelleted by centrifugation at 0.5 relative centrifugal force $(\mathrm{RCF}) \times 1 \mathrm{~min}$, resuspended in $0.5 \%$ trypsin (Invitrogen), and incubated at $37^{\circ} \mathrm{C}$ for $4.5 \mathrm{~min}$. The cells were dispersed by pipetting at the 2 -min time point and end of the incubation period. The incubation was terminated by adding culture medium (RPMI 1640 supplemented with 10\% non-heat inactivated FBS (Hyclone, Logan, UT, USA), $100 \mathrm{U} / \mathrm{ml}$ penicillin, $100 \mu \mathrm{g} / \mathrm{ml}$ streptomycin, and $2 \mathrm{mmol} / 1$ glutamine). The dispersed cells were collected by centrifugation $(0.5 \mathrm{RCF} \times 5 \mathrm{~min})$, resuspended in culture medium, and plated onto tissue culture dishes (BD-Falcon, San Jose, CA, USA). MIN6 cells were cultured as previously described (Miyazaki et al. 1990).

MIN6 cells or dispersed murine islet cells were plated in a cell media volume of $1.5 \mathrm{ml}$ at a density of $1.0 \times 10^{5}$ or $2 \cdot 0 \times 10^{5}$ cells per $35-\mathrm{mm}$ tissue culture dish respectively. Transfection with siRNA was carried out 5 or $24 \mathrm{~h}$ after plating for dispersed murine islets or MIN6 cells respectively. Cells were transfected with control (negative control siRNA \#3, Dharmacon, Lafayette, CO, USA) or ZnT8 siRNA (Nicolson et al. 2009; see Supplementary Table 1 for sequence of the ZnT8 siRNA) by adding $500 \mu \mathrm{l}$ of transfection mix $(500 \mu \mathrm{l}$ Opti-MEM-I transfection medium (Invitrogen), 150 pmol siRNA (final concentration $75 \mathrm{nM}$, Dharmacon), and $7 \mu \mathrm{l}$ Lipofectamin RNAimax (Invitrogen), prepared according to the manufacturer's instructions). In MIN6 cell experiments, the cell culture medium was exchanged for antibiotic-free standard cell culture medium immediately prior to transfection. Cells were maintained in this mix of culture and transfection medium until experiments were carried out $72 \mathrm{~h}$ later. In each experiment, cells were transfected with ZnT8 siRNA or non-targeting control siRNA in parallel. Decreased ZnT8 mRNA and protein levels were verified using real-time PCR and western blot analysis (see below).

\section{Western blot analysis}

Western blot analysis of cell lysates was carried out as described previously (Liu et al. 2001), with modifications as described herein. Samples (20 $\mu$ g of protein) were suspended in $\beta$-mercaptoethanol ( $\beta$-ME)-containing laemmli buffer without heating and subjected to $10 \%$ SDS-PAGE followed by semi dry transfer for $2 \mathrm{~h}$ to a polyvinylidene fluoride membrane (Immobilon-P, Millipore, Bedford, MA, USA). The membranes were blocked for $2 \mathrm{~h}$ and then hybridized overnight with a 1:2000 dilution of polyclonal rabbit-anti-rat ZnT8 antibody (Mellitech, Grenoble, France). The membranes were then washed $\times 3$ for $10 \mathrm{~min}$ in Tris-Buffered Saline Tween-20 (TBS-T) and hybridized with a 1:7500 dilution of secondary antibody (HRP-conjugated goat antirabbit IgG, Promega) for $1 \mathrm{~h}$. The membrane was washed $\times 3$ for $10 \mathrm{~min}$ in TBS-T. Immunoreactive bands were detected using an ECL detection kit (Amersham). All of the above steps were carried out at $4{ }^{\circ} \mathrm{C}$ on ice. The blocking and antibody incubation steps were carried out in TBS-T containing $5 \% \mathrm{w} / \mathrm{v}$ non-fat milk powder (Carnation, Wilkes-Barre, PA, USA). To document equivalent loading of protein, the immunoblots were stripped in $62.5 \mathrm{mM}$ Tris$\mathrm{HCl}$ (pH 6.7), 20\% SDS, and $100 \mathrm{mM} \beta-\mathrm{ME}$ for $30 \mathrm{~min}$ at $50{ }^{\circ} \mathrm{C}$, rehybridized with a monoclonal mouse anti-mouse GAPDH antibody (Cell Signalling, Danvers, MA, USA), and an HRP-coupled secondary goat anti-mouse antibody.

\section{Glucose-stimulated insulin secretion and total cellular insulin content}

To measure glucose-stimulated insulin secretion (GSIS), dispersed murine islet cells were washed three times with PBS $72 \mathrm{~h}$ after transfection. Subsequently, the cells were equilibrated in HEPES-buffered Krebs solution (130 mM $\mathrm{NaCl}, 3.6 \mathrm{mM} \mathrm{KCl}, 0.5 \mathrm{mM} \mathrm{NaH}{ }_{2} \mathrm{PO}_{4}, 0.5 \mathrm{mM} \mathrm{MgSO}_{4}$, $1.5 \mathrm{mM} \mathrm{CaCl}_{2}, 1 \%$ HEPES, $0 \cdot 1 \% \mathrm{BSA}$, pH 7.4) containing $5.6 \mathrm{mM}$ glucose for $30 \mathrm{~min}$. This was followed by incubation in HEPES-buffered Krebs solution with $5.6 \mathrm{mM}$ glucose for $30 \mathrm{~min}$, and then HEPES-buffered Krebs solution with $16.7 \mathrm{mM}$ glucose for $30 \mathrm{~min}$. After each period of incubation, $200 \mu \mathrm{l}$ of the supernatant was collected. Samples were stored at $-80^{\circ} \mathrm{C}$. In separate experiments, cells were incubated for $72 \mathrm{~h}$ following transfection and then lysed after washing three times with PBS by adding $100 \mu$ of RIPA lysis buffer supplemented with a cocktail of protease and phosphatase inhibitors (Calbiochem, Madison, WI, USA). Total protein concentration in the lysate was measured using the Micro BCA Protein Assay kit (Pierce, Thermo Fisher Scientific, Waltham, MA, USA) according to the 
manufacturer's recommendations. Measurement of insulin was carried out by ELISA (Alpco Diagnostics, San Francisco, CA, USA) according to the manufacturer's instructions.

\section{Cell viability}

Cell viability experiments were performed in black, opaque 96-well tissue culture plates (BD-Falcon). Dispersed murine islet cells were cultured and transfected with either control or ZnT8 siRNA as described above with proportional adjustment for the decreased culture area. The medium was supplemented with $\mathrm{ZnCl}_{2}$ to final concentrations of $\mathrm{Zn}$ of $5,19,34,48,62,76,91$, or $105 \mu \mathrm{M}$ at the time of transfection. Cell viability was assessed $72 \mathrm{~h}$ post transfection using the double fluorescence Multitox assay (Promega) according to the manufacturer's instructions. Briefly, $100 \mu \mathrm{l}$ of the assay mix was added to each well and incubated at $37^{\circ} \mathrm{C}$ for $2 \mathrm{~h}$. Fluorescence was measured on a fluorescence plate reader at excitation wavelength (Ex) $400 \mathrm{~nm} /$ emission wavelength (Em) $505 \mathrm{~nm}$ and Ex 485/Em 520 , which measured fluorescence from proteases in viable and dead cells respectively. Fluorescence values were transformed to dead and live cell readout values using a standard curve obtained using a standardized range of cell densities for the live cell signal and digitonin-induced cell death for the dead cell signal. Readout values were normalized to values obtained from untreated cells. Results were reported as a cell viability index calculated as the ratio of live cell to dead cell readouts.

\section{Measurement of $Z n$ concentration in the media}

Inductively coupled plasma mass spectrometry (ICP-MS) was used to measure $\mathrm{Zn}$ content in the culture media. The media were diluted with ultra-pure laboratory grade water (Millipore, Billerica, MA, USA), and an internal standard mixture of $\mathrm{Sc}, \mathrm{Tb}, \mathrm{Y}$, In, and $\mathrm{Bi}$ (CPI International, Santa Rosa, CA, USA) was added to this solution. Standards between 0 and $90 \mathrm{ppb}$ were made using a mixed element solution (CPI International). $2 \% \mathrm{v} / \mathrm{v}$ trace metal grade nitric acid (Fisher Scientific, Pittsburgh, PA, USA) was added to the standards and samples. All measurements were performed on an XSeries II ICP-MS instrument (Thermo Scientific, Waltham, MA, USA).

\section{Statistical analysis}

Results are reported as means \pm s.E.M. unless otherwise stated. The ' $n$ ' represents the number of independent experiments performed. Changes in parameters normalized to the control condition were tested for statistical significance using a two-sided $t$-test with unequal variance to account for the normalization to the control. In all other experiments comparing the effects of various treatments on physiological parameters not normalized to the control, groups were compared directly to the control condition using a two-sided $t$-test with equal variance. $P$ values $\leq 0 \cdot 05$ and 0.005 were considered statistically significant and highly significant respectively (STATA-IC V.10.1, College Station, TX, USA).

\section{Results}

\section{Cytokine-induced alterations in expression of $Z n$ transporters}

Initial studies compared the expression profile of members of the ZnT and ZIP families in MIN6 cells and primary murine islets. As shown in Fig. 1, mRNAs encoding 14 members of the ZIP family and nine members of the $\mathrm{ZnT}$ family are expressed in murine islets. The expression profile of the $\mathrm{ZnTs}$ and ZIPs in MIN6 cells was comparable to that in islets with the exception of a markedly lower expression of ZnT2, ZnT3, ZIP4, and ZIP5.

Having established comparable expression profiles of $\mathrm{Zn}$ transporters in islets and MIN6 cells, MIN6 cells were used as a model to examine the impact of cytokines on the level of mRNAs encoding the different $\mathrm{Zn}$ transporters. Treatment of MIN6 cells with either $5 \mathrm{ng} / \mathrm{ml}$ IL1 $\beta$ or $10 \mathrm{ng} / \mathrm{ml} \mathrm{TNF} \alpha$ for $24 \mathrm{~h}$ altered the expression of several $\mathrm{Zn}$ transporters (Fig. 2). The transporters with the most marked change in expression were ZnT8 and ZIP4. The level of ZnT8 mRNA was decreased by $54 \cdot 6 \pm 6 \cdot 9$ and $44 \cdot 7 \pm 5 \cdot 4 \%$ by IL1 $\beta$ and TNF $\alpha$ respectively $(P=0 \cdot 004$ and $0 \cdot 004$, Fig. $2 \mathrm{C})$. The level of ZIP4 mRNA was increased $14 \pm 4 \cdot 2$-fold after IL1 $\beta$ treatment
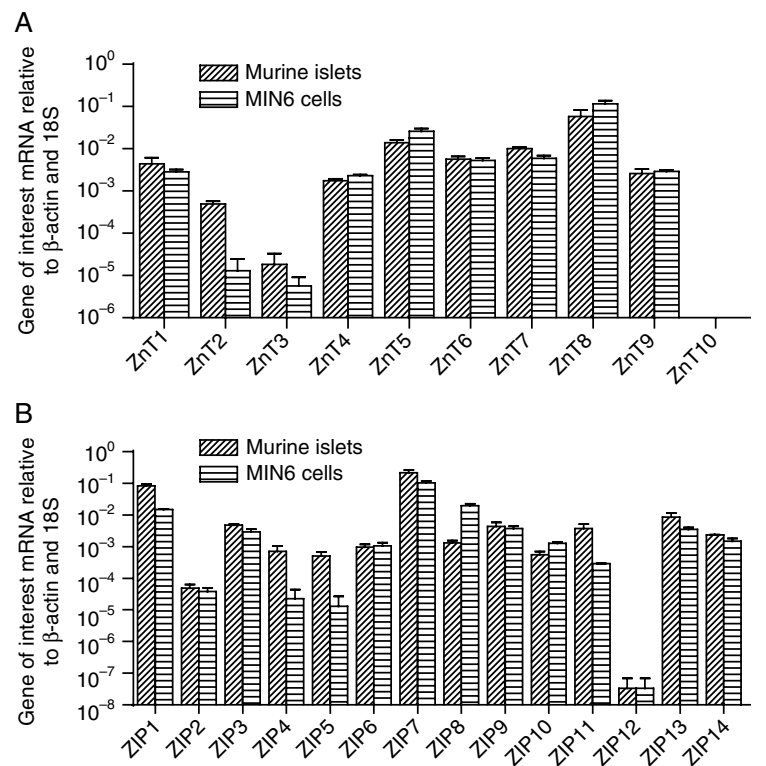

Figure 1 Relative level of mRNAs encoding ZIP and ZnT transporters in MIN6 cells and murine islets. mRNA was extracted from untreated murine islets and MIN6 cells, and real-time PCR was performed. mRNA levels were normalized to both $\beta$-actin and $18 \mathrm{~S}$. Values represent the relative level of ZIP or ZnT mRNA normalized to the level of both $\beta$-actin and $18 \mathrm{~S}$ mRNA, and are the mean \pm s.E.M. of the results of three independent experiment. 


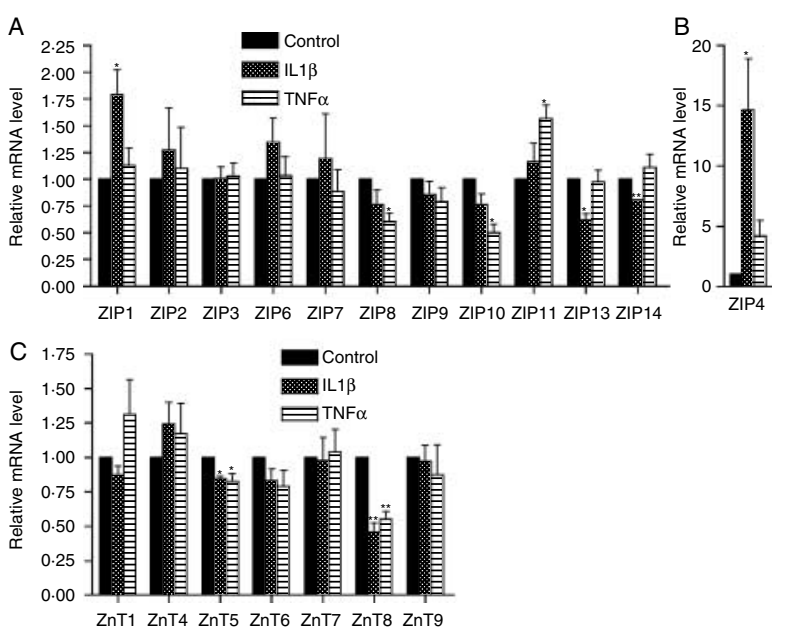

Figure 2 Effect of cytokines on ZIP and ZnT mRNA levels in MIN6 cells. MIN6 cells were treated for $24 \mathrm{~h}$ with $5 \mathrm{ng} / \mathrm{ml} \mathrm{IL} 1 \beta$ or $10 \mathrm{ng} / \mathrm{ml} \mathrm{TNF} \alpha$, and the level of mRNAs encoding ZIPs (A and B) and $\mathrm{ZnTs}(\mathrm{C})$ was determined. Values represent the relative level of mRNA compared with the level in control cells, which was defined as 1.0 and represent the mean \pm S.E.M. $(n=4-5$ for the different transporters). ${ }^{*} P<0 \cdot 05$ compared with control; $* * P<0 \cdot 005$ compared with control.

$(P<0 \cdot 05$, Fig. 2B). There was also a trend, albeit not significant, toward increased expression of ZIP4 mRNA following treatment with TNF $\alpha(4 \cdot 1 \pm 1 \cdot 2$-fold, $P=0 \cdot 089$, Fig. 2B). Treatment for $48 \mathrm{~h}$ with a combination of $5 \mathrm{ng} / \mathrm{ml}$ IL1 $\beta$ and $10 \mathrm{ng} / \mathrm{ml}$ TNF $\alpha$ decreased ZnT8 mRNA by $50 \pm 14 \%(P=0 \cdot 024$, Fig. 3C), while ZIP4 mRNA levels showed a clear but statistically non-significant trend toward increased expression $(21 \pm 7 \cdot 6$-fold, $P=0 \cdot 057$, Fig. 3D). In time course experiments, IL1 $\beta$ treatment decreased $\mathrm{ZnT} 8$ mRNA levels by $51 \pm 4 \cdot 2 \%, 54 \cdot 6 \pm 6 \cdot 9 \%$, and $64 \cdot 1 \pm 0 \cdot 6 \%$ following treatment for 6, 24, and $48 \mathrm{~h}$ respectively (Fig. 3A). Treatment with $10 \mathrm{ng} / \mathrm{ml}$ TNF $\alpha$ for $6 \mathrm{~h}$ had no effect on ZnT8 mRNA levels but decreased ZnT8 mRNA levels by $44 \cdot 7 \pm 5 \cdot 4$ and $50 \pm 5 \cdot 2 \%$ after treatment for 24 and $48 \mathrm{~h}$ respectively (Fig. 3A). IL1 $\beta$ treatment for 6,24 , and $48 \mathrm{~h}$ increased ZIP4 mRNA levels by $16 \pm 1 \cdot 2-, 14 \pm 4 \cdot 2-$, and $47 \pm 4 \cdot 1$-fold respectively (Fig. 3B). Treatment with TNF $\alpha$ for 6,24 , and $48 \mathrm{~h}$ stimulated a nonsignificant trend toward increased ZIP4 mRNA levels with increases of $6 \cdot 8 \pm 1 \cdot 2-$, $4 \cdot 1 \pm 1 \cdot 2-$, and $13 \pm 3 \cdot 5$-fold respectively (Fig. 3B).

Subsequent experiments determined whether cytokines had a similar effect on ZnT8 and ZIP4 mRNA levels in murine islets. Treatment of islets with $5 \mathrm{ng} / \mathrm{ml}$ IL1 $\beta$ for $24 \mathrm{~h}$ decreased ZnT8 mRNA levels by $81 \pm 7 \%$, while treatment for $24 \mathrm{~h}$ with $10 \mathrm{ng} / \mathrm{ml} \mathrm{TNF} \alpha$ decreased ZnT8 mRNA levels by $68 \pm 11 \%(P=0 \cdot 0012$ and $0 \cdot 009$, Fig. $4 \mathrm{~A})$. Treatment of islets with $5 \mathrm{ng} / \mathrm{ml}$ IL1 $\beta$ for $24 \mathrm{~h}$ showed a trend toward increased ZIP4 mRNA levels $(3 \cdot 81 \pm 0 \cdot 75$-fold, $P=0 \cdot 064$, Fig. 4B). Treatment with $10 \mathrm{ng} / \mathrm{ml}$ TNF $\alpha$ for $24 \mathrm{~h}$ resulted in a similar nonsignificant trend toward increased ZIP4 mRNA levels $(2 \cdot 62 \pm 0 \cdot 50$-fold, $P=0 \cdot 083$, Fig. 4B).
$\beta$-Cell labile $Z n$ distribution and cytokine-induced changes of labile $\mathrm{Zn}$

Laser scanning confocal imaging of live MIN6 cells following incubation with Fluozin-3 AM showed a high concentration of labile $\mathrm{Zn}$ (unbound or weakly bound intracellular $\mathrm{Zn}$ ), which appeared to be distributed primarily in secretory vesicles (Fig. 5A). Given the changes in $\mathrm{Zn}$ transporter expression induced by cytokine treatment, we examined the changes in labile, FluoZin-3 AM-detectable $\mathrm{Zn}$ in $\beta$-cells after cytokine treatment which, based upon the live cell imaging, represents primarily $\mathrm{Zn}$ present in secretory vesicles. In order to avoid interference by other cell types contained in islets, we used the pancreatic $\beta$-cell line MIN6. After $24 \mathrm{~h}$ treatment with $5 \mathrm{ng} / \mathrm{ml} \mathrm{IL1} \beta$, the average $\mathrm{Zn}$-related FluoZin-3 AM fluorescence decreased by $22 \cdot 2 \pm 8 \cdot 8 \%$ compared with control cells $(P=0 \cdot 0012$, Fig. 5B).

\section{Effect of an acute decrease in ZnT8 expression on GSIS}

Given the high baseline expression of ZnT8, its localization to insulin secretory granules, and the marked cytokine-induced changes in ZnT8 mRNA levels, we investigated the effect of an acute downregulation of ZnT8 mRNA levels in $\beta$-cells using siRNA. Initial studies demonstrated the ability of ZnT8 siRNA to decrease the level of ZnT8 mRNA. Following transfection of MIN6 or primary dispersed murine islet cells with ZnT8 siRNA, the level of ZnT8 mRNA was $23 \pm 1 \cdot 4$ and $54 \cdot 4 \pm 4 \cdot 4 \%$ (mean \pm s.E.M.) of the level in cells
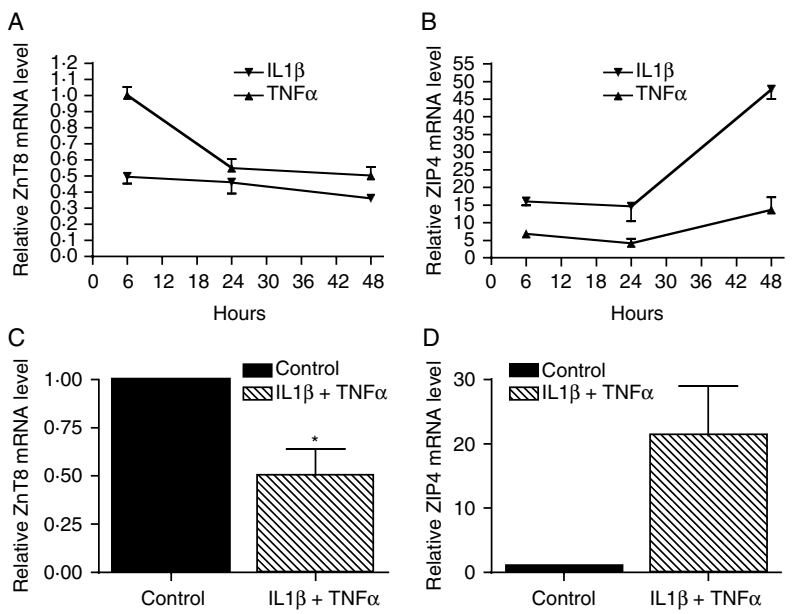

Figure 3 ( $A$ and $B$ ) Time course of effect of cytokines on ZnT8 and ZIP4 mRNA levels. The level of ZnT8 (A) and ZIP4 (B) mRNA was determined in MIN6 cells after treatment with $5 \mathrm{ng} / \mathrm{ml} \mathrm{IL1} \beta$ or $10 \mathrm{ng} / \mathrm{ml} \mathrm{TNF} \alpha$ for $6(n=2), 24(n=4)$, or $48(n=2) \mathrm{h}$. Values represent the relative level of ZnT8 and ZIP4 mRNA compared with the level in control cells, and are the mean \pm s.E.M. (C and D) Effect of a combination of cytokines on ZnT8 and ZIP4 mRNA levels. The level of ZnT8 (C) and ZIP4 (D) mRNA was determined in MIN6 cells after treatment with a combination of $5 \mathrm{ng} / \mathrm{ml} \mathrm{IL1} \beta$ and $10 \mathrm{ng} / \mathrm{ml}$ TNF $\alpha$ for $48 \mathrm{~h}$. Values represent the relative level of ZnT8 and ZIP4 mRNA compared with the level in control cells, and are the mean \pm s.E.M. $(n=5) .{ }^{*} P<0 \cdot 05$. 

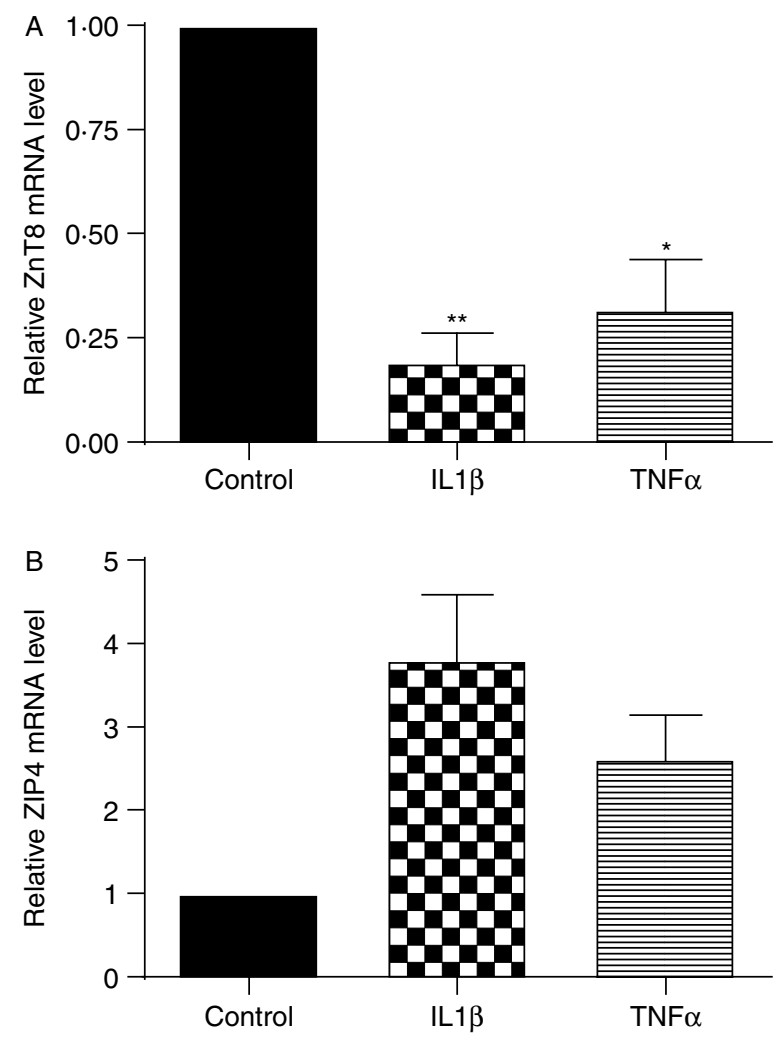

Figure 4 Effect of cytokines on ZnT8 and ZIP4 mRNA levels in intact murine islets. ZnT8 (A) and ZIP4 (B) mRNA levels were determined in intact murine islets after treatment for $24 \mathrm{~h}$ with $5 \mathrm{ng} / \mathrm{ml} \mathrm{IL1} \beta$ or $10 \mathrm{ng} / \mathrm{ml} \mathrm{TNF} \alpha$. Values are the mean level of ZnT8 and ZIP4 mRNA compared with the level in control cells, which was defined as 1.0 and are the mean \pm S.E.M. $(n=4$ for $Z n T 8, n=3$ for ZIP4). ${ }^{*} P<0 \cdot 05,{ }^{* *} P<0 \cdot 005$ compared with control.

transfected with control siRNA respectively (Fig. 6A). A decrease in ZnT8 protein level in dispersed primary murine islets following treatment with $\mathrm{ZnT} 8$ siRNA was verified by western blotting (Fig. 6B).

Having established that ZnT8 siRNA was able to decrease ZnT8 expression, GSIS in dispersed murine islet cells following transfection with $\mathrm{ZnT} 8$ or control siRNA was determined. The relative ratio of insulin concentration in medium following incubation in $16 \cdot 7$ compared with $5 \cdot 6 \mathrm{mM}$ glucose was $2 \cdot 0 \pm 0 \cdot 25$ in cells treated with control siRNA (Fig. 7A), while in islet cells treated with $\mathrm{ZnT} 8$ siRNA, the ratio was significantly decreased to $1 \cdot 2 \pm 0 \cdot 21$ $(P<0.05$ compared with the ratio in cells transfected with control siRNA). In contrast to the effect on GSIS, transfection with ZnT8 siRNA did not affect total cellular insulin content. Total cellular insulin content in islet cell lysates was $17 \cdot 1 \pm 1.5 \mathrm{ng}$ insulin/ $\mu \mathrm{g}$ protein following transfection with ZnT8 siRNA compared with $15 \cdot 3$ $\pm 1.6 \mathrm{ng}$ insulin $/ \mu \mathrm{g}$ protein following transfection with control siRNA $(P=0 \cdot 41$, Fig. $7 \mathrm{~B})$.
Effects of decreased ZnT8 mRNA levels on labile $\mathrm{Zn}$

We next examined whether acute downregulation of ZnT8 expression altered $\mathrm{Zn}$ homeostasis similar to treatment with IL $\beta$. For these studies, MIN6 cells were transfected with either ZnT8 or control siRNA, and labile Zn was determined using flow cytometry after staining with the $\mathrm{Zn}$-specific fluorescent probe FluoZin-3 AM and the live-cell dye CellTrace calcein red-orange AM. The relative mean labile $\mathrm{Zn}$-related fluorescence from live cells decreased by 26.5 $\pm 17 \cdot 6 \%$ following transfection with $\mathrm{ZnT} 8$ siRNA compared with control siRNA $(P<0 \cdot 05$, Fig. $8 A)$.

Effect of decreased ZnT8 $m R N A$ levels on islet cell viability in various $Z n$ concentrations

Subsequent studies examined the impact of decreased ZnT8 expression and the resulting changes in $\mathrm{Zn}$ homeostasis on islet cell viability. Initial studies using ICP-MS demonstrated that the concentration of $\mathrm{Zn}$ in the culture medium was $5 \mu \mathrm{M}$. Following transfection of dispersed murine islet cells with
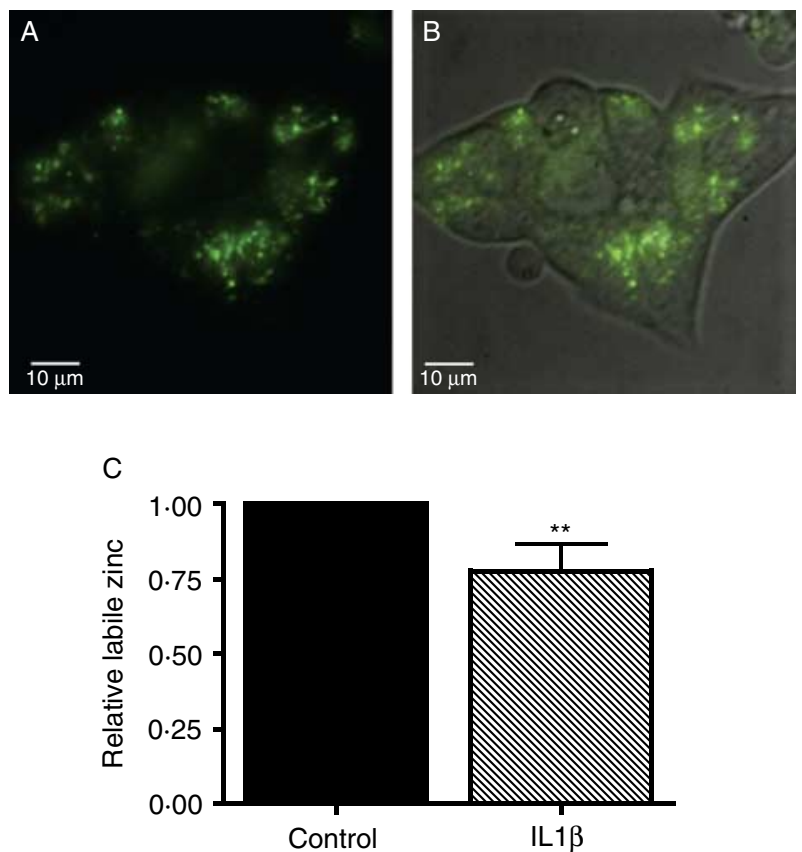

Figure 5 ( $A$ and $B$ ) The distribution of labile $\mathrm{Zn}$ in single untreated live MIN6 cells. Labile $\mathrm{Zn}$ was imaged following incubation in Fluozin-3 AM in phenol red-free DMEM for 30 min using confocal spinning disc microscopy $(100 \times$ magnification, A, Fluozin-3 AM fluorescence alone; $B$, phase contrast + fluorescence overlay). (C) Effect of IL1 $\beta$ on labile $Z n$ in MIN6 cells. Cells were analyzed using flow cytometry after staining with the $\mathrm{Zn}$-specific fluorescent probe FluoZin-3 AM and live-cell dye CellTrace calcein red-orange, AM. FluoZin-3 AM fluorescence was analyzed in live cells only. In total, 20 000-30 000 live cell events were recorded in each replicate. The change in FluoZin-3 AM detectable $\mathrm{Zn}$ was determined in MIN6 cells after treatment or not with $5 \mathrm{ng} / \mathrm{ml} \mathrm{IL} 1 \beta$ for $24 \mathrm{~h}$. Values represent the relative FluoZin-3 AM-related fluorescence in live cells normalized to the control condition, and are the mean \pm S.E.M. $\left(n=3\right.$, each in triplicate). ${ }^{* *} P<0 \cdot 005$ compared with control. 


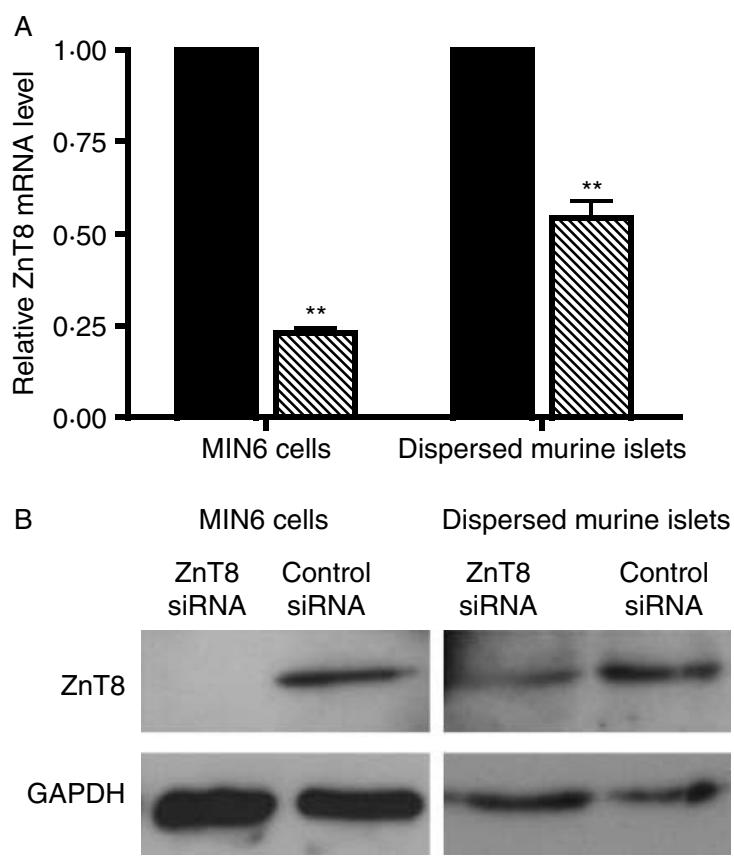

Figure 6 Effect of ZnT8 siRNA on ZnT8 expression. (A) ZnT8 mRNA levels were determined in MIN6 and dispersed murine islet cells following transfection with either ZnT8 or control siRNA. The values represent the relative level of ZnT8 mRNA in cells treated with ZnT8 siRNA compared with cells treated with control siRNA, which was defined as $1 \cdot 0$, and are the mean \pm S.E.M. ( $n=3$ for MIN6 cells, $n=4$ for islet cells). The level of ZnT8 mRNA was normalized to the level of $\beta$-actin mRNA. ${ }^{* *} P<0 \cdot 005$ compared with control siRNA.

(B) Western blot analysis comparing ZnT8 in dispersed murine islet cells treated with ZnT8 siRNA and control siRNA. The autoradiograms are representative of the results of three and five independent experiments for MIN6 and dispersed islets respectively.

either ZnT8 or control siRNA, cell viability was determined using the Multitox assay. The viability indices, which are proportional to the ratio of live to dead cells each normalized to the values of control cells with no added $\mathrm{Zn}$, were $1 \cdot 0002$ \pm 0.0004 and $0.9937 \pm 0 \cdot 0070$ following transfection with control and ZnT8 siRNAs respectively $(P=0 \cdot 386, n=4$, each performed in duplicate or triplicate, Fig. 8B). Supplementing the medium with $\mathrm{ZnCl}_{2}$ to final $\mathrm{Zn}$ concentrations of 19,34 , $48,62,76,91$, or $105 \mu \mathrm{M}$ enhanced cell viability at all concentrations. The viability index increased to 1.5803 \pm 0.0608 and $1.5493 \pm 0.1017$ at $105 \mu \mathrm{M} \mathrm{Zn}$ in cells transfected with control and ZnT8 siRNAs respectively $(P=0.802$ for the knockdown versus control comparison, $n=4$, each performed in duplicate or triplicate).

\section{Discussion}

Impaired function of human and rodent $\beta$-cells as well as MIN6 cells after exposure to IL1 $\beta$ or TNF $\alpha$ is well established (Donath et al. 2008). Several potential mechanisms have been suggested for this effect (Xenos et al. 1992, 1993, 1994, Corbett \& McDaniel 1995, Rabinovitch \& Suarez-Pinzon
1998, Wu et al. 2001, Donath et al. 2008). These include activation of the mitogen-activated protein kinases, c-jun N-terminal kinase, p38, and Extracellular Signal-RegulatedKinase (ERK) with subsequent activation of the nuclear factor kappa-light-chain-enhancer of activated $\beta$-cells $(\mathrm{NF}-\kappa \mathrm{B})$ pathway and altered gene expression (Donath et al. 2008). In this study, we examined whether cytokines affect $\mathrm{Zn}$ transporter expression as a possible contributing factor to cytokine-induced $\beta$-cell dysfunction. We demonstrated that treatment of murine islets or MIN6 cells with IL1 $\beta$ or TNF $\alpha$ alters the expression profile of $\mathrm{Zn}$ transporters of the $\mathrm{ZnT}$ and ZIP families. One of the observed changes which may be of particular significance is the cytokine-induced decrease in ZnT8 expression. ZnT8 has a high baseline expression level in $\beta$-cells, and plays an important role in $\beta$-cell function. Moreover, we observed similar alterations in cellular labile
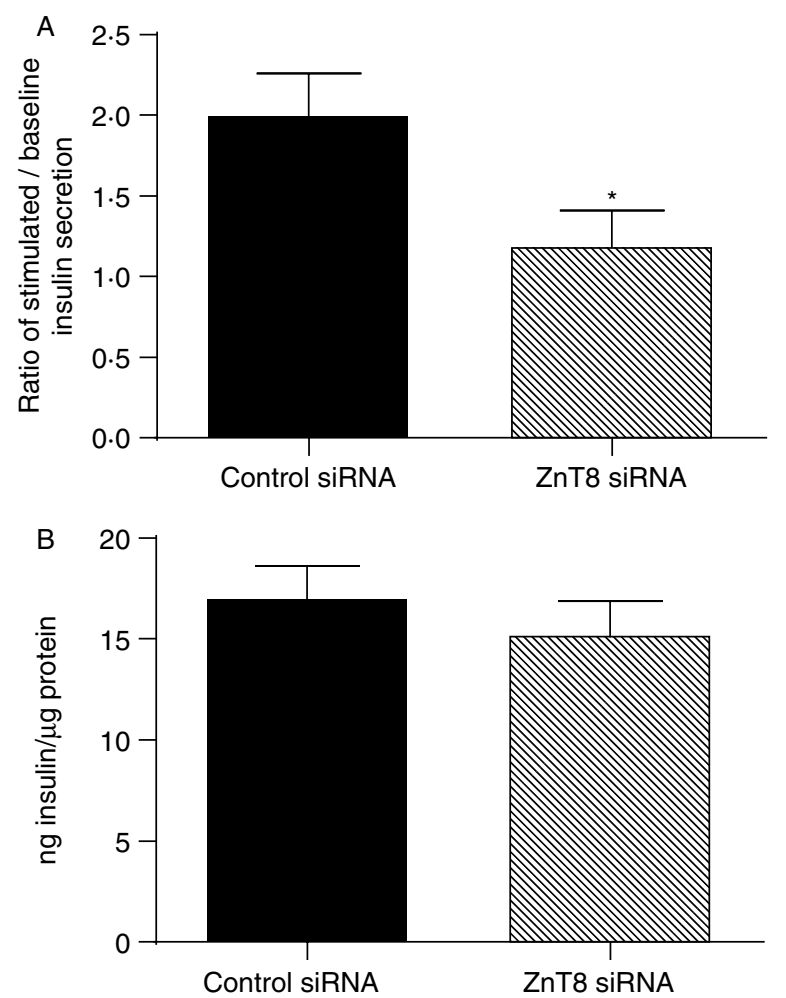

Figure 7 Glucose-stimulated insulin secretion and cellular insulin content in dispersed murine islet cells following transfection with ZnT8 siRNA. (A) $72 \mathrm{~h}$ after transfection of dispersed murine islet cells with either ZnT8 or control siRNA, the insulin concentration in the medium was determined following incubation in 5.6 and $16.7 \mathrm{mM}$ glucose. Values represent the ratio of the insulin concentration in medium after incubation for $30 \mathrm{~min}$ in $16.7 \mathrm{mM}$ glucose compared with $5.6 \mathrm{mM}$ glucose, and are the mean \pm s.E.M. $(n=4) .{ }^{*} P<0 \cdot 05$ compared with cells treated with control siRNA. (B) Total cellular content of insulin in dispersed murine islet cells $72 \mathrm{~h}$ after transfection with either ZnT8 or control siRNA. Values represent the total insulin content in cell lysates which was determined as described in the Materials and Methods, and are the mean \pm S.E.M. $(n=3)$. 

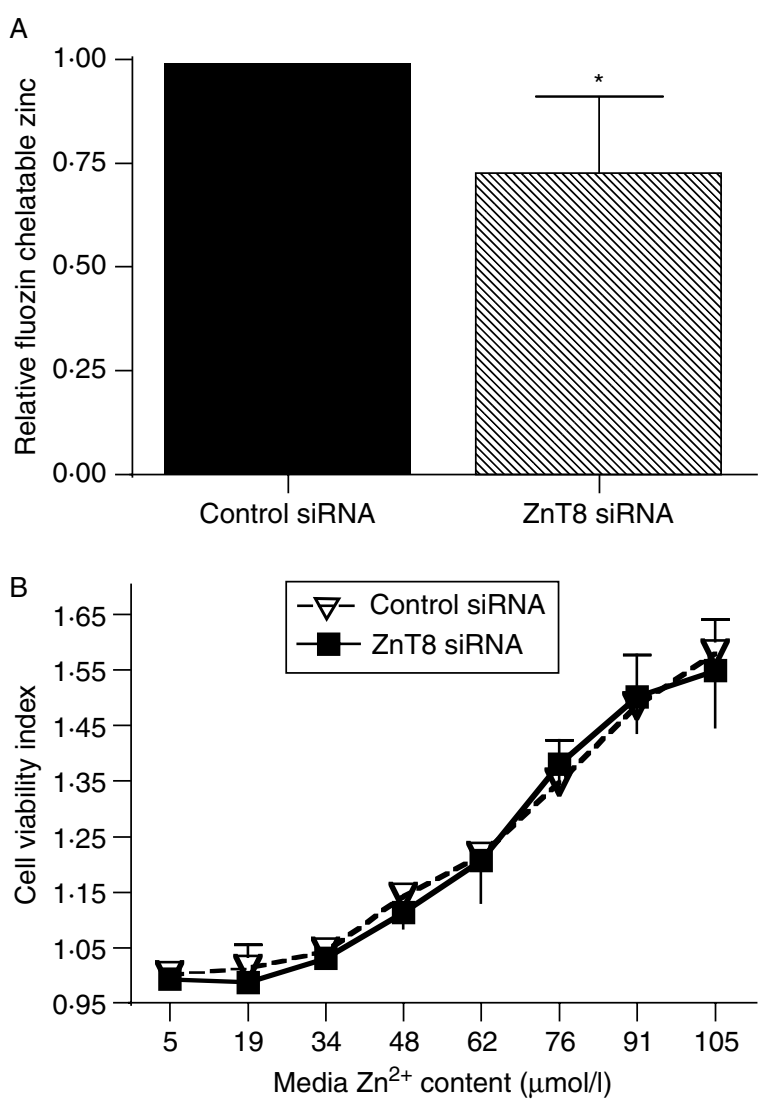

Figure 8 Effect of decreased ZnT8 expression on MIN6 cell labile $\mathrm{Zn}$ content and dispersed islet cell viability. (A) MIN6 cells were analyzed using flow cytometry after staining with the Zn-specific fluorescent probe FluoZin-3 AM and live-cell dye CellTrace calcein red-orange. FluoZin-3 AM fluorescence was analyzed in live cells only. In total, 20 000-30 000 live cell events were recorded in each replicate. FluoZin-3-chelatable $\mathrm{Zn}$ in MIN6 cells transfected with control siRNA or ZnT8 siRNA was then determined. Values represent the relative FluoZin-3-related fluorescence in live cells normalized to the control condition, and are the mean \pm s.E.M. $(n=3$, each in duplicate or triplicate), $* P<0 \cdot 05$. (B) Dispersed islet cells were transfected with either ZnT8 or control siRNA, and then incubated in the presence of increasing concentrations of Zn. Cell viability was determined using the Multitox assay. Changes in the cell viability index correspond to changes in the ratio of the live to dead cell readouts. Values represent the mean cell viability index, and are the mean \pm s.D. of the results $(n=4$, each in duplicate or triplicate).

Zn content following IL1 $\beta$ exposure and ZnT8 knockdown. This finding and the decrease in GSIS observed following $\mathrm{ZnT}$ 8 knockdown are consistent with alterations in $\mathrm{Zn}$ homeostasis due to decreased $\mathrm{ZnT}$ 8 expression contributing to cytokine-induced impairment of $\beta$-cell function.

Our finding of a cytokine-induced decrease in ZnT8 expression generally agrees with a recent report by Egefjord et al. (2009) which described an IL1 $\beta$-induced decrease in ZnT8 mRNA levels in INS-1 cells, a rat $\beta$-cell line, as well as in rat islets. In contrast to their findings, we did not observe reduced ZnT3, ZnT6, and ZIP6 mRNA levels; however, we do find a significant cytokine-induced increase in ZIP4 mRNA levels. It is likely that these differences relate to differences in the models used.

$\mathrm{Zn}$ is critical for the function of mammalian cells. The vast majority of the intracellular $\mathrm{Zn}$ is bound to proteins or is accrued in specialized compartments (Suhy et al. 1999, Hambidge 2000, Colvin et al. 2003, Lemire et al. 2007). A vanishingly small amount of free $\mathrm{Zn}$ is typically available in the cytosol of most cells (Suhy et al. 1999, Outten \& O'Halloran 2001, Bozym et al. 2006). In most cells, $\mathrm{Zn}$ is important for the structural integrity and function of transcription factors in the $\mathrm{Zn}$ finger family of proteins and for maintaining proper function of $\mathrm{Zn}$-dependent enzymes that protect cells against oxidative stress and apoptosis (Truong-Tran et al. 2001, Prasad et al. 2004). The cellular content of $\mathrm{Zn}$ in $\beta$-cells is markedly higher than most mammalian cells, which is likely related to its unique roles in $\beta$-cells (Chausmer 1998, Dodson \& Steiner 1998, Chimienti et al. 2005, Cousins et al. 2006). Estimates suggest that $\sim 50 \%$ of $\mathrm{Zn}$ in $\beta$-cells is present within secretory vesicles (Zalewski et al. 1994), where it has been postulated to play a role in the packaging of proinsulin and insulin as hexamers. In this model, $\mathrm{Zn}$ enables storage of insulin at high concentrations and facilitates adequate insulin release in response to a glucose load (Huber \& Gershoff 1973, Figlewicz et al. 1984, Huang \& Arvan 1995, Dodson \& Steiner 1998, Chimienti et al. 2005, 2006).

ZnT8 is highly expressed in $\beta$-cells (Chimienti et al. 2005, 2006), and localizes mainly to membranes of secretory vesicles, suggesting that it plays an important role in $\mathrm{Zn}$ transport into $\beta$-cell secretory vesicles (Chimienti et al. 2006, Mocchegiani et al. 2008). As noted earlier, overexpression of ZnT8 enhanced the insulin secretory capacity of a $\beta$-cell line (Chimienti et al. 2006). On the other hand, an R325W mutation in SLC30A8 is associated with type 2 diabetes as well as decreased first phase insulin secretion in non-diabetic subjects bearing at least one copy of the risk allele (Saxena et al. 2007, Scott et al. 2007, Sladek et al. 2007, Zeggini et al. 2007, Boesgaard et al. 2008, Hertel et al. 2008, van Hoek et al. 2008, Horikawa et al. 2008, Omori et al. 2008, Wu et al. 2008, Xiang et al. 2008). Complete loss of ZnT8 expression in mice homozygous for a null mutation of SLC30A8 led to decreased $\mathrm{Zn}$ accumulation in islets (Lemaire et al. 2009, Nicolson et al. 2009, Pound et al. 2009). ZnT8 null mice also exhibited decreased GSIS and altered glucose homeostasis (Pound et al. 2009). However, ZnT8 null mice exhibited altered glucose tolerance as well as in vivo and in vitro disturbances in GSIS only under certain age, gender, and dietary conditions (Lemaire et al. 2009, Nicolson et al. 2009). Furthermore, an unexpected increase in weight gain was observed in ZnT8 null mice fed a high fat diet (Nicolson et al. 2009). Given these observations, secondary effects during various developmental stages as well as environmental interactions are likely to have influenced the findings in this global knockout model. In the present study, we have now demonstrated that an acute decrease in $\mathrm{ZnT} 8$ expression in 
dispersed murine islet cells decreases GSIS in cells without altering the total cellular insulin content. In contrast to the global ZnT8 knockout mouse model, our model demonstrates the impact of an isolated, acute decrease in ZnT8 function prior to the induction of compensatory changes during development. This approach furthers our understanding of $\beta$-cell physiology by examining the impact of decreased ZnT8 expression independent of potential developmental changes or secondary compensatory mechanisms present in the $\mathrm{ZnT}$ 8 knockout model.

ZnT8 knockout models demonstrated decreased GSIS under certain age and dietary conditions without changes in total cellular insulin content (Lemaire et al. 2009, Nicolson et al. 2009, Pound et al. 2009). This similarity between the effects of acutely decreased ZnT8 expression and chronic, complete loss of ZnT8 expression in the knockout mice indicates that $\beta$-cells have a limited capacity to compensate for changes in $\mathrm{Zn}$ homeostasis. Our findings and those in $\mathrm{ZnT}$ 8 knockout mice in which decreased or absent ZnT8 expression did not impact total cellular insulin content differ from data obtained using the INS-1 $\beta$-cell line after an siRNA-mediated decrease in ZnT8 expression (Fu et al. 2009). In that model, both the number of insulin-containing secretory vesicles and total cellular insulin content were decreased after ZnT8 knockdown. These differences may be due to differences in the physiology of primary islet cells and INS cells.

The effect of decreased ZnT8 expression on GSIS in murine islet cells could be due to one or more possible mechanisms. Decreased ZnT8 expression likely results in reduced transport of $\mathrm{Zn}$ into secretory vesicles, which would impair the packaging of insulin as hexamers around $\mathrm{Zn}$ cores and thereby alter insulin secretion (Huang \& Arvan 1995, Dodson \& Steiner 1998). Another possible mechanism would be a toxic effect of $\mathrm{Zn}$ accumulation in the cytoplasm exceeding the metal-buffering capacity of cytoplasmic proteins (Frederickson et al. 1989, Koh et al. 1996, Kim et al. 1999a,b, Lobner et al. 2000, Frederickson et al. 2005, Lecane et al. 2005, Lemire et al. 2007, Oyama et al. 2007, Park et al. 2007, Zhang et al. 2007, Matsui et al. 2008). To examine this, we studied the changes in labile $\mathrm{Zn}$ with decreased $\mathrm{ZnT}$ 8 expression in MIN6 cells using the fluorescent $\mathrm{Zn}$ probe FluoZin-3 AM. This approach has been previously validated for $\mathrm{Zn}$ in MIN6 cells (Gee et al. 2002). A significant decrease in intracellular FluoZin-3 AM-detectable Zn, which correlated with decreased ZnT8 expression, was observed. FluoZin-3 AM is reported to have a moderate binding affinity for $\mathrm{Zn}\left(K_{\mathrm{d}}\right.$ of $15 \mathrm{nM}$ per the manufacturer) which is a significantly lower affinity for $\mathrm{Zn}$ than that of typical Zn-binding enzymes such as carbonic anhydrase (Bozym et al. 2006). Thus, Zn detected by FluoZin-3 AM represents the fraction of cellular $\mathrm{Zn}$ that is loosely bound to assorted intracellular ligands that have a lower affinity for Zn. Most cytoplasmic $\mathrm{Zn}$ is reported to be bound to metallothioneins, which have a much higher affinity for Zn than FluoZin-3 AM (Jacob et al. 1998). Therefore, it is unlikely that the
FluoZin-3 AM signal reflects cytosolic Zn unless labile Zn concentrations exceed the buffering capacity of the abundant metallothioneins present in the cytoplasm of $\beta$-cells (Laychock et al. 2000, Li et al. 2004). FluoZin-3 AM is known to penetrate intracellular vesicles, and, consistent with our imaging of FluoZin-3 AM loaded live $\beta$-cells, it is likely that the majority of the labile $\mathrm{Zn}$ detected using FluoZin-3 AM is present within secretory vesicles. Taken together, our results suggest that acute downregulation of $\mathrm{ZnT} 8$ reduces the capacity of $\beta$-cells to accumulate $\mathrm{Zn}$ in $\beta$-cell insulin secretory vesicles.

The present studies also demonstrated that decreased ZnT8 expression did not have a significant impact on islet cell viability at the physiological $\mathrm{Zn}$ concentration of $5 \mu \mathrm{mol} / \mathrm{l}$ or in the presence of supraphysiological concentrations of $\mathrm{Zn}$ (up to $105 \mu \mathrm{mol} / \mathrm{l}$ ) in the growth medium (Isbir et al. 1994, Sampson et al. 1997, Chausmer 1998, Maret \& Sandstead 2006). In contrast to other cell types, $\beta$-cells have been shown to tolerate supraphysiological ambient $\mathrm{Zn}$ concentrations $<200 \mu \mathrm{mol} / 1$ (Huber \& Gershoff 1973, Figlewicz et al. 1981, Frederickson et al. 1989, Koh et al. 1996, Kim et al. 1999a,b, 2000, Lobner et al. 2000, Chang et al. 2003, Frederickson et al. 2005, Lecane et al. 2005, Lemire et al. 2007, Oyama et al. 2007, Park et al. 2007, Zhang et al. 2007, Matsui et al. 2008). The absence of toxic effects following ZnT8 knockdown in cells exposed to $105 \mu \mathrm{mol} / 1 \mathrm{Zn}$ in our study suggests that impaired GSIS with decreased ZnT8 expression is not likely due to toxic effects secondary to free $\mathrm{Zn}$ accumulation in the cytoplasm.

Given the low level of ZIP4 mRNA, the physiologic relevance of the increase in ZIP4 expression following exposure to IL1 $\beta$ is uncertain. ZIP4 regulates $\mathrm{Zn}$ influx into the cytoplasm of various mammalian cell types. In intestinal enterocytes, ZIP4 is located in the apical cell membrane and facilitates the uptake of sufficient quantities of dietary Zn. ZIP4 expression is reported to increase in $\mathrm{Zn}$-deficient intestinal cells through posttranscriptional mRNA stabilization as well as decreased protein degradation (Dufner-Beattie et al. 2003, Weaver et al. 2007, Andrews 2008). Little is known about the role of ZIP4 in the pancreas, although ZIP4 was reported to be aberrantly expressed in pancreatic cancer (Li et al. 2007). Based upon the real-time PCR assay, the expression of ZIP4 mRNA was relatively low compared with other $\mathrm{Zn}$ transporters but increased following cytokine exposure. It is possible that this represents a compensatory response to the IL1 $\beta$-induced decrease in labile $\mathrm{Zn}$ (Fig. 5B). Future studies will be needed to address that issue; specifically, the level of ZIP4 protein and changes in response to cytokine exposure and/or ZnT8 knockdown will need to be examined.

This study highlights the importance of the $\mathrm{Zn}$ transporter ZnT8 in pancreatic $\beta$-cell physiology. Beyond demonstrating a critical role for ZnT8 in GSIS, our findings suggest that cytokine-mediated $\beta$-cell dysfunction may occur, in part, through disruption of $\mathrm{Zn}$ metabolism via decreased ZnT8 expression. 


\section{Supplementary data}

This is linked to the online version of the paper at http://dx.doi.org/10.1677/ JOE-09-0420.

\section{Declaration of interest}

The authors declare that there is no conflict of interest that could be perceived as prejudicing the impartiality of the research reported.

\section{Funding}

This study was funded by a Northwestern Memorial Foundation MD-Scientist Fellowship in Genetic Medicine award for ME. The study was also funded by two NIH grants: R37GM038784 (TVO) and U42RR023245 (TVO) and T32 DK007169-27 NRSA Institutional Training Grant (LKB). Imaging was performed at the Northwestern University Cell Imaging Facility generously supported by CCSG P30 CA060553 awarded to the Robert H Lurie Comprehensive Cancer Center. ICP-MS Metal analysis was performed at the Northwestern University Quantitative Bioelemental Imaging Center generously supported by NASA Ames Research Center NNA04CC36G.

\section{References}

Andrews GK 2008 Regulation and function of Zip4, the acrodermatitis enteropathica gene. Biochemical Society Transactions 36 1242-1246.

Blomeier H, Zhang X, Rives C, Brissova M, Hughes E, Baker M, Powers AC, Kaufman DB, Shea LD \& Lowe WL Jr 2006 Polymer scaffolds as synthetic microenvironments for extrahepatic islet transplantation. Transplantation $\mathbf{8 2}$ 452-459.

Boesgaard TW, Zilinskaite J, Vanttinen M, Laakso M, Jansson PA, Hammarstedt A, Smith U, Stefan N, Fritsche A, Haring H et al. 2008 The common SLC30A8 Arg325Trp variant is associated with reduced first-phase insulin release in 846 non-diabetic offspring of type 2 diabetes patients - the EUGENE2 study. Diabetologia 51 816-820.

Bozym RA, Thompson RB, Stoddard AK \& Fierke CA 2006 Measuring picomolar intracellular exchangeable zinc in PC-12 cells using a ratiometric fluorescence biosensor. ACS Chemical Biology 1 103-111.

Chang I, Cho N, Koh JY \& Lee MS 2003 Pyruvate inhibits zinc-mediated pancreatic islet cell death and diabetes. Diabetologia 46 1220-1227.

Chausmer AB 1998 Zinc, insulin and diabetes. Journal of the American College of Nutrition 17 109-115.

Chimienti F, Favier A \& Seve M 2005 ZnT-8, a pancreatic $\beta$-cell-specific zinc transporter. Biometals 18 313-317.

Chimienti F, Devergnas S, Pattou F, Schuit F, Garcia-Cuenca R, Vandewalle B, Kerr-Conte J, Van Lommel L, Grunwald D, Favier A et al. 2006 In vivo expression and functional characterization of the zinc transporter ZnT8 in glucose-induced insulin secretion. Journal of Cell Science 119 4199-4206.

Chin-Chance CV, Newman MV, Aronovitz A, Blomeier H, Kruger J, Lee EJ \& Lowe WL Jr 2006 Role of the mitogen-activated protein kinases in cytokine-mediated inhibition of insulin gene expression. Journal of Investigative Medicine $\mathbf{5 4}$ 132-142.

Colvin RA, Fontaine CP, Laskowski M \& Thomas D $2003 \mathrm{Zn}^{2+}$ transporters and $\mathrm{Zn}^{2+}$ homeostasis in neurons. European Journal of Pharmacology 479 171-185.

Corbett JA \& McDaniel ML 1995 Intraislet release of interleukin 1 inhibits $\beta$ cell function by inducing $\beta$ cell expression of inducible nitric oxide synthase. Journal of Experimental Medicine 181 559-568.

Cousins RJ, Liuzzi JP \& Lichten LA 2006 Mammalian zinc transport, trafficking, and signals. Journal of Biological Chemistry 281 24085-24089.

Dodson G \& Steiner D 1998 The role of assembly in insulin's biosynthesis. Current Opinion in Structural Biology 8 189-194.

Donath MY, Storling J, Berchtold LA, Billestrup N \& Mandrup-Poulsen T 2008 Cytokines and $\beta$-cell biology: from concept to clinical translation. Endocrine Reviews 29 334-350.
Dufner-Beattie J, Wang F, Kuo YM, Gitschier J, Eide D \& Andrews GK 2003 The acrodermatitis enteropathica gene ZIP4 encodes a tissue-specific, zincregulated zinc transporter in mice. Journal of Biological Chemistry 278 33474-33481.

Dupuis J, Langenberg C, Prokopenko I, Saxena R, Soranzo N, Jackson AU, Wheeler E, Glazer NL, Bouatia-Naji N, Gloyn AL et al. 2010 New genetic loci implicated in fasting glucose homeostasis and their impact on type 2 diabetes risk. Nature Genetics 42 105-116.

Egefjord L, Jensen JL, Bang-Berthelsen CH, Petersen AB, Smidt K, Schmitz O, Karlsen AE, Pociot F, Chimienti F, Rungby J et al. 2009 Zinc transporter gene expression is regulated by pro-inflammatory cytokines: a potential role for zinc transporters in $\beta$-cell apoptosis? BMC Endocrine Disorder 97.

Figlewicz DP, Heldt A, Forhan SE \& Grodsky GM 1981 Effect of exogenous zinc on insulin secretion in vitro. Endocrinology 108 730-732.

Figlewicz DP, Forhan SE, Hodgson AT \& Grodsky GM 1984 65Zinc and endogenous zinc content and distribution in islets in relationship to insulin content. Endocrinology 115 877-881.

Frederickson CJ, Hernandez MD \& McGinty JF 1989 Translocation of zinc may contribute to seizure-induced death of neurons. Brain Research $\mathbf{4 8 0}$ 317-321.

Frederickson CJ, Koh JY \& Bush AI 2005 The neurobiology of zinc in health and disease. Nature Reviews. Neuroscience 6 449-462.

Fu Y, Tian W, Pratt EB, Dirling LB, Shyng SL, Meshul CK \& Cohen DM 2009 Down-regulation of ZnT8 expression in INS-1 rat pancreatic $\beta$ cells reduces insulin content and glucose-inducible insulin secretion. PLOS ONE 4 e5679.

Gee KR, Zhou ZL, Qian WJ \& Kennedy R 2002 Detection and imaging of zinc secretion from pancreatic $\beta$-cells using a new fluorescent zinc indicator. Journal of the American Chemical Society 124 776-778.

Hambidge M 2000 Human zinc deficiency. Journal of Nutrition 130 1344S-1349S.

Hertel JK, Johansson S, Raeder H, Midthjell K, Lyssenko V, Groop L, Molven A \& Njolstad PR 2008 Genetic analysis of recently identified type 2 diabetes loci in 1,638 unselected patients with type 2 diabetes and 1,858 control participants from a Norwegian population-based cohort (the HUNT study). Diabetologia 51 971-977.

van Hoek M, Dehgan A, Witteman JC, van Duijn CM, Uitterlinden AG, Oostra BA, Hofman A, Sijbrands EJ \& Janssens AC 2008 Predicting type 2 diabetes based on polymorphisms from genome wide association studies: a population-based study. Diabetes $\mathbf{5 7}$ 3122-3128.

Horikawa Y, Miyake K, Yasuda K, Enya M, Hirota Y, Yamagata K, Hinokio Y, Oka Y, Iwasaki N, Iwamoto Y et al. 2008 Replication of genome-wide association studies of type 2 diabetes susceptibility in Japan. Journal of Clinical Endocrinology and Metabolism 93 3136-3141.

Huang XF \& Arvan P 1995 Intracellular transport of proinsulin in pancreatic $\beta$-cells. Structural maturation probed by disulfide accessibility. Journal of Biological Chemistry 270 20417-20423.

Huber AM \& Gershoff SN 1973 Effect of zinc deficiency in rats on insulin release from the pancreas. Journal of Nutrition 103 1739-1744.

Isbir T, Tamer L, Taylor A \& Isbir M 1994 Zinc, copper and magnesium status in insulin-dependent diabetes. Diabetes Research 26 41-45.

Jacob C, Maret W \& Vallee BL 1998 Control of zinc transfer between thionein, metallothionein, and zinc proteins. PNAS 95 3489-3494.

Kim EY, Koh JY, Kim YH, Sohn S, Joe E \& Gwag BJ 1999a Zn ${ }^{2+}$ entry produces oxidative neuronal necrosis in cortical cell cultures. European Journal of Neuroscience 11 327-334.

Kim YH, Kim EY, Gwag BJ, Sohn S \& Koh JY $1999 b$ Zinc-induced cortical neuronal death with features of apoptosis and necrosis: mediation by free radicals. Neuroscience 89 175-182.

Kim BJ, Kim YH, Kim S, Kim JW, Koh JY, Oh SH, Lee MK, Kim KW \& Lee MS 2000 Zinc as a paracrine effector in pancreatic islet cell death. Diabetes 49 367-372.

Koh JY, Suh SW, Gwag BJ, He YY, Hsu CY \& Choi DW 1996 The role of zinc in selective neuronal death after transient global cerebral ischemia. Science 272 1013-1016.

Laychock SG, Duzen J \& Simpkins CO 2000 Metallothionein induction in islets of Langerhans and insulinoma cells. Molecular and Cellular Endocrinology $165179-187$ 
Lecane PS, Karaman MW, Sirisawad M, Naumovski L, Miller RA, Hacia JG \& Magda D 2005 Motexafin gadolinium and zinc induce oxidative stress responses and apoptosis in B-cell lymphoma lines. Cancer Research 65 11676-11688.

Lemaire K, Ravier MA, Schraenen A, Creemers JW, Van de Plas R, Granvik M, Van Lommel L, Waelkens E, Chimienti F, Rutter GA et al. 2009 Insulin crystallization depends on zinc transporter $\mathrm{ZnT} 8$ expression, but is not required for normal glucose homeostasis in mice. PNAS 106 14872-14877.

Lemire J, Mailloux R \& Appanna VD 2007 Zinc toxicity alters mitochondrial metabolism and leads to decreased ATP production in hepatocytes. Journal of Applied Toxicology 28 175-182.

Li X, Chen H \& Epstein PN 2004 Metallothionein protects islets from hypoxia and extends islet graft survival by scavenging most kinds of reactive oxygen species. Journal of Biological Chemistry 279 765-771.

Li M, Zhang Y, Liu Z, Bharadwaj U, Wang H, Wang X, Zhang S, Liuzzi JP, Chang SM, Cousins RJ et al. 2007 Aberrant expression of zinc transporter ZIP4 (SLC39A4) significantly contributes to human pancreatic cancer pathogenesis and progression. PNAS 104 18636-18641.

Liu W, Liu Y \& Lowe WL Jr 2001 The role of phosphatidylinositol 3-kinase and the mitogen-activated protein kinases in insulin-like growth factor-Imediated effects in vascular endothelial cells. Endocrinology 142 1710-1719.

Livak KJ \& Schmittgen TD 2001 Analysis of relative gene expression data using real-time quantitative PCR and the $2(-$ Delta Delta $C(T))$ method. Methods 25 402-408.

Lobner D, Canzoniero LM, Manzerra P, Gottron F, Ying H, Knudson M, Tian M, Dugan LL, Kerchner GA, Sheline CT et al. 2000 Zinc-induced neuronal death in cortical neurons. Cellular and Molecular Biology 46 797-806.

Maret W \& Sandstead HH 2006 Zinc requirements and the risks and benefits of zinc supplementation. Journal of Trace Elements in Medicine and Biology 20 3-18.

Matsui H, Sakanashi Y, Oyama TM, Oyama Y, Yokota S, Ishida S, Okano Y, Oyama TB \& Nishimura Y 2008 Imidazole antifungals, but not triazole antifungals, increase membrane $\mathrm{Zn}^{2+}$ permeability in rat thymocytes possible contribution to their cytotoxicity. Toxicology 248 142-150.

Milne DB, Ralston NV \& Wallwork JC 1985 Zinc content of blood cellular components and lymph node and spleen lymphocytes in severely zincdeficient rats. Journal of Nutrition 115 1073-1078.

Miyazaki J, Araki K, Yamato E, Ikegami H, Asano T, Shibasaki Y, Oka Y \& Yamamura K 1990 Establishment of a pancreatic $\beta$ cell line that retains glucose-inducible insulin secretion: special reference to expression of glucose transporter isoforms. Endocrinology 127 126-132.

Mocchegiani E, Giacconi R \& Malavolta M 2008 Zinc signalling and subcellular distribution: emerging targets in type 2 diabetes. Trends in Molecular Medicine 14 419-428.

Nicolson TJ, Bellomo EA, Wijesekara N, Loder MK, Baldwin JM, Gyulkhandanyan AV, Koshkin V, Tarasov AI, Carzaniga R, Kronenberger K et al. 2009 Insulin storage and glucose homeostasis in mice null for the granule zinc transporter $\mathrm{ZnT} 8$ and studies of the type 2 diabetes-associated variants. Diabetes $\mathbf{5 8}$ 2070-2083.

Omori S, Tanaka Y, Takahashi A, Hirose H, Kashiwagi A, Kaku K, Kawamori R, Nakamura Y \& Maeda S 2008 Association of CDKAL1, IGF2BP2, CDKN2A/B, HHEX, SLC30A8, and KCNJ11 with susceptibility to type 2 diabetes in a Japanese population. Diabetes $\mathbf{5 7} 791-795$.

Outten CE \& O'Halloran TV 2001 Femtomolar sensitivity of metalloregulatory proteins controlling zinc homeostasis. Science 292 2488-2492.

Oyama Y, Matsui H, Morimoto M, Sakanashi Y, Nishimura Y, Ishida S \& Okano Y 2007 Synergic cytotoxic action induced by simultaneous application of zinc and clotrimazole in rat thymocytes. Toxicology Letters 171 138-145.

Park SE, Park JW, Cho YS, Ryu JH, Paick JS \& Chun YS 2007 HIF-1 $\alpha$ promotes survival of prostate cells at a high zinc environment. Prostate $\mathbf{6 7}$ $1514-1523$.

Pound LD, Sarkar S, Benninger RK, Wang Y, Suwanichkul A, Shadoan MK, Printz RL, Oeser JK, Lee CE, Piston DW et al. 2009 Deletion of the mouse Slc30a8 gene encoding zinc transporter-8 results in impaired insulin secretion. Biochemical Journal 421 371-376.

Prasad AS, Bao B, Beck FW, Kucuk O \& Sarkar FH 2004 Antioxidant effect of zinc in humans. Free Radical Biology \& Medicine 37 1182-1190.

Rabinovitch A \& Suarez-Pinzon WL 1998 Cytokines and their roles in pancreatic islet $\beta$-cell destruction and insulin-dependent diabetes mellitus. Biochemical Pharmacology 55 1139-1149.
Sampson B, Kovar IZ, Rauscher A, Fairweather-Tait S, Beattie J, McArdle HJ, Ahmed R \& Green C 1997 A case of hyperzincemia with functional zinc depletion: a new disorder? Pediatric Research 42 219-225.

Saxena R, Voight BF, Lyssenko V, Burtt NP, de Bakker PI, Chen H, Roix JJ, Kathiresan S, Hirschhorn JN, Daly MJ et al. 2007 Genome-wide association analysis identifies loci for type 2 diabetes and triglyceride levels. Science $\mathbf{3 1 6}$ $1331-1336$

Scott LJ, Mohlke KL, Bonnycastle LL, Willer CJ, Li Y, Duren WL, Erdos MR, Stringham HM, Chines PS, Jackson AU et al. 2007 A genome-wide association study of type 2 diabetes in Finns detects multiple susceptibility variants. Science 316 1341-1345.

Sladek R, Rocheleau G, Rung J, Dina C, Shen L, Serre D, Boutin P, Vincent D, Belisle A, Hadjadj S et al. 2007 A genome-wide association study identifies novel risk loci for type 2 diabetes. Nature 445 881-885.

Suhy DA, Simon KD, Linzer DI \& O'Halloran TV 1999 Metallothionein is part of a zinc-scavenging mechanism for cell survival under conditions of extreme zinc deprivation. Journal of Biological Chemistry 274 9183-9192.

Truong-Tran AQ, Carter J, Ruffin RE \& Zalewski PD 2001 The role of zinc in caspase activation and apoptotic cell death. Biometals 14 315-330.

Wallwork JC, Johnson LK, Milne DB \& Sandstead HH 1983 The effect of interactions between dietary egg white protein and zinc on body weight, bone growth and tissue trace metals in the 30-day-old rat. Journal of Nutrition 113 1307-1320

Ward NI \& Mason JA 1987 Neuron activation analysis techniques for identifying elemental status in Alzheimer's disease. Journal of Radioanalytical and Nuclear Chemistry 113 515-526.

Weaver BP, Dufner-Beattie J, Kambe T \& Andrews GK 2007 Novel zincresponsive post-transcriptional mechanisms reciprocally regulate expression of the mouse Slc39a4 and Slc39a5 zinc transporters (Zip4 and Zip5). Biological Chemistry 388 1301-1312.

Wu JJ, Chen X, Cao XC, Baker MS \& Kaufman DB 2001 Cytokine-induced metabolic dysfunction of MIN6 $\beta$ cells is nitric oxide independent. Journal of Surgical Research 101 190-195.

Wu Y, Li H, Loos RJ, Yu Z, Ye X, Chen L, Pan A, Hu FB \& Lin X 2008 Common variants in CDKAL1, CDKN2A/B, IGF2BP2, SLC30A8 and HHEX/IDE genes are associated with type 2 diabetes and impaired fasting glucose in a Chinese Han population. Diabetes 57 2834-2842.

Xenos ES, Farney AC, Widmer MB, Casanova D, Stevens RB, Blazar BR, Sutherland DE \& Gores PF 1992 Effect of tumor necrosis factor $\alpha$ and of the soluble tumor necrosis factor receptor on insulin secretion of isolated islets of Langerhans. Transplantation Proceedings 24 2863-2864.

Xenos ES, Stevens RB, Gores PF, Casanova D, Farney AC, Sutherland DE \& Platt JL 1993 IL-1 $\beta$-induced inhibition of $\beta$-cell function is mediated through nitric oxide. Transplantation Proceedings 25994.

Xenos ES, Stevens RB, Sutherland DE, Lokeh A, Ansite JD, Casanova D, Gores PF \& Platt JL 1994 The role of nitric oxide in IL-1 $\beta$-mediated dysfunction of rodent islets of Langerhans. Implications for the function of intrahepatic islet grafts. Transplantation 57 1208-1212.

Xiang J, Li XY, Xu M, Hong J, Huang Y, Tan JR, Lu X, Dai M, Yu B \& Ning G 2008 Zinc transporter-8 gene (SLC30A8) is associated with type 2 diabetes in Chinese. Journal of Clinical Endocrinology and Metabolism 93 4107-4112.

Zalewski PD, Millard SH, Forbes IJ, Kapaniris O, Slavotinek A, Betts WH, Ward AD, Lincoln SF \& Mahadevan I 1994 Video image analysis of labile zinc in viable pancreatic islet cells using a specific fluorescent probe for zinc. Journal of Histochemistry and Cytochemistry 42 877-884.

Zeggini E, Weedon MN, Lindgren CM, Frayling TM, Elliott KS, Lango H, Timpson NJ, Perry JR, Rayner NW, Freathy RM et al. 2007 Replication of genome-wide association signals in UK samples reveals risk loci for type 2 diabetes. Science 316 1336-1341.

Zhang Y, Aizenman E, Defranco DB \& Rosenberg PA 2007 Intracellular zinc release, 12-lipoxygenase activation and MAPK dependent neuronal and oligodendroglial death. Molecular Medicine 13 350-355.

Received in final form 10 May 2010

Accepted 27 May 2010

Made available online as an Accepted Preprint 27 May 2010 